\title{
Is the evolving sport of mountain biking compatible with fauna conservation in national parks?
}

\author{
Shelley Burgin ${ }^{1, *}$ and Nigel Hardiman ${ }^{2}$
}

'Mirvac School of Sustainable Development, Bond University, Gold Coast, Queensland, Australia, 4229.

${ }^{2}$ University of Kent, School of Anthropology and Conservation, Canterbury Campus, Kent, CT2 7NZ

*Corresponding author: Professor Shelley Burgin,

Mirvac School of Sustainable Development, Gold Coast, Queensland, Australia, 4229.

\section{Email: sburgin@bond.edu.au}

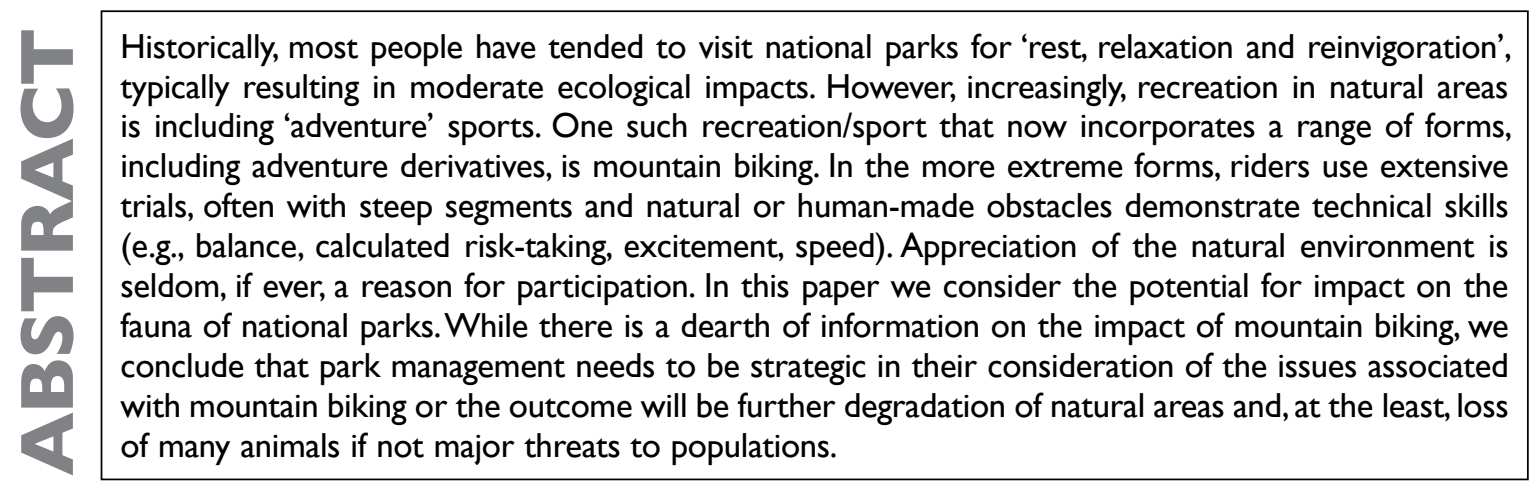

Key words: fauna management, adventure sports, native animals, environmental impact, bike trails, natural area, visitor attitudes

\section{Introduction}

Historically, most people have tended to visit national parks for 'rest, relaxation and reinvigoration', and their ecological impact was typically considered to be low (Hall et al. 2010). More recently; however, there has been increasing use of national parks for more active recreation, 'adventure' sports, including rock climbing, abseiling, canyoning, whitewater kayaking, skiing, offroad driving and mountain biking (Hardiman and Burgin, 2011a).

'Adventure recreation' is defined as 'outdoor activities in which the uncontrollable hazards of a natural environment or feature are deliberately challenged through the application of specially-developed skills and judgment' (Brown 1989, pp. 37). Such sports have been criticised for their impacts, for example rock bolting (Jones, 2004), vegetation loss (Groom et al. 2007) and soil erosion (Ewert and Hollenhorst 1994). However, more recently some forms of 'adventure recreation' have been morphing into 'extreme sports'. These comprise a constantly-evolving collection of new sports or extension of existing ones which pose an increased risk of ecological impacts. As the term implies, extreme sports typically push the existing boundaries of risk for thrill's own sake with the aim of inducing an adrenaline 'buzz' by overcoming fear. This is induced by speed, gravity, and/or height (Ewert et al. 2006, Carnicelli-Filho et al. 2010). Typical examples of extreme sports are speed rock climbing, waterfall kayaking, BASE (Buildings, Antennas,
Spans, Earth) jumping, heliskiing, enduro motocross and downhill mountain biking. Such forms of recreation typically depend on large, undeveloped landscapes, for example national parks or other protected areas with a biological conservation mandate (Ewert et al. 2006).

One difference between adventure recreation and extreme sports is the emphasis on thrill as an end product (Puchan 2005). Another difference is that extreme sports typically involve competition among participants. This further changes the mental dynamic and the motivation for visiting the natural area. Such aspects switch the primary objective from 'experiencing' (passive recreation) to 'conquering or beating' nature (Baker and Simon 2002). Extreme sports often commence as niche activities, either as a completely new derivative or from another, less extreme form and subsequently develop into mainstream forms of recreation in their own right, even becoming Olympic events (e.g., Starr et al. 2006; IFSC 2010). One example of an adventure recreational activity that is evolving into a more extreme version is mountain biking. With its increasing international popularity (Bradshaw 2006; Koepke 2005; Leberman and Mason 2000), there is an associated rising demand for purpose-built trails and infrastructure, potentially within national parks and other natural areas. In this paper we consider the evolving sport of mountain biking: is it compatible with nature conservation in national parks or could it become an ecological disaster? 


\section{The evolving sport of mountain biking}

Mountain biking is assumed to have originated in the United States of America (US) in the 1970s (White et al. 2006). It now has global participation (Koepke 2005), and has become probably the most popular land-based recreation in the world (White et al. 2006). Koepke (2005) estimated that between 1987 and 2000 the popularity of mountain biking increased four-fold. By 2003 approximately 10 million in the United States of America (US) regularly used mountain bikes (Green 2003) and approximately $21 \%$ of the US population is estimated to cycle on backcountry roads, trails, or across country at least annually (White et al. 2006). Although sales have slowed in recent years, mountain/hybrid bikes still represented $44 \%$ of unit sales through US speciality bicycle retailers between 2006-2008 (NBDA 2010). The sport is also increasingly popular in Europe. For example, in the United Kingdom (UK), 5.7\% of the population is estimated to mountain bike regularly (TRC 2005), while elsewhere, for example in Germany (3.5 million mountain bikers), Switzerland and Austria (800,000 combined) participation is also growing (Koepke 2005). In Australia, the sport grew by $15.3 \%$ between 2001 and 2004 (Faulks et al. 2008), and of the 753,843 bikes sold in 2004, 70\% were mountain bikes (Bradshaw 2006). Globally, the sport continues to grow in popularity, and the International Mountain Biking Association (IMBA) is today represented in 17 countries (IMBA 2010).

In the traditional form of mountain biking, i.e. 'crosscountry/recreational', riders use lightweight bicycles to traverse a range of landscapes on rides typically lasting a few hours. Emphasis is on relaxation, exercise and appreciation of natural scenery (Chiu \& Kriwoken 2003) especially on single-track trails where riders are segregated from cars and can enjoy a closer connection to nature (Koepke 2005). Although cross-country/recreational riding is still the most popular, mainstream form of the sport (89\% of US; $97 \%$ of UK mountain bike riders), more physically challenging, extreme derivatives are growing in popularity. Such derivatives include 'downhill' (18\% US; $22.2 \%$ UK), 'freeriding' (23\% US; 21.2\% UK) and 'trials' (14\% US; 8.1\% UK) (Cessford 1995; Green 2003; Koepke 2005; Gajda 2008; IMBA 2010).

'Downhill' mountain biking involves steep descent over rough terrain at high speed using heavy, specialist bikes with long-travel suspension. The focus is on speed, strength and calculated risk-taking to make the fastest possible descent against the clock. For protection, riders wear plastic body amour and full-face helmets. They are typically transported to the top of the racecourses/runs by ski lift, 4WD vehicle or helicopter (Cessford 1995; TRC 2005). In another extreme derivative, 'Free-riding' (cf. 'North Shore'), riders are challenged to overcome natural and/or man-made obstacles (e.g., elevated, narrow wooden boardways, log rides, ladder bridges and teeter-totters) on purpose-built circuits (Cessford 1995; Koepke 2005). The focus is on demonstrating technical skills, balance, calculated risk-taking, excitement, and speed. Similar to downhilling, appreciation of the natural environment is seldom, if ever, a reason for participation (see e.g., Tiedeman 2002; Leberman and Mason 2000; Chiu and Kriwoken 2003; Cessford 1995).

The increasing popularity and associated economic potential for 'destination mountain biking tourism' has been widely acknowledged. For example, US locations such as Moab (Utah) and Fruita (Colorado) each offer hundreds of kilometres of single track bike trails (MATC 2010; OTES 2010). Alpine ski resorts of Canada, such as Whistler Blackcomb, have more than $200 \mathrm{~km}$ of biking trails which include 34 trails of lift-serviced downhill routes (TRC 2005; Whistler Blackcomb undated). In Scotland, the 7stanes, part of the UK's 40-site network of dedicated mountain bike centres, offers $600 \mathrm{~km}$ of forest trails (TRC 2005). New Zealand also has extensive mountain biking opportunities (Cessford 1995; Ride Rotorua undated), and the sport is becoming increasingly popular in Australia (Chiu and Kriwoken 2003). This is reflected, for example in the expansion of mountain biking within Sydney (e.g., HSMBA undated).

\section{Physical impacts of mountain biking}

The rapidly increasing popularity of mountain biking, together with its concurrent evolution into different forms, has caused concern surrounding its potential ecological impacts. Ecological impacts associated with recreational trails generally emanate from their initial design and construction and subsequent use (e.g., type, user behaviour, frequency, and intensity; Sun and Walsh 1998). Problems in assessing such impacts are complex. For example, most natural area trail use is a shared resource with other forms of recreation, typically including bush walking, horse riding, and 4WD driving. The specific impacts due to mountain biking therefore often cannot be readily distinguished (Hendricks et al. 2001). Despite this, instances of the creation of unauthorised, informal bike trails and/or construction of technical track features such as concrete-reinforced jumps and wooden boardways used in freeriding/North Shore mountain biking are becoming commonplace in national parks in Australia (e.g., Davies and Newsome 2009).

On flat terrain under dry conditions, impacts on trails caused by recreational mountain biking, include increased water runoff and sediment yield, vegetation and species loss, and/or soil exposure generally have been found to be comparable with those of walking tracks, although less than motorised vehicle use or horse riding (Wilson and Seney 1994; Thurston and Reader 2001; Chiu and Kriwoken 2003). The potential for trail erosion, compaction, incision and widening from mountain biking is, however dependent on climate, slope and other environmental variables. Steep slopes with sparse vegetation and/or fine homogenous soils are most susceptible to damage (Goeft and Alder 2001; White et al. 2006). The greatest impacts from biking typically occur early in trail use, on downhill (braking and skidding) and uphill (wheel spinning) slopes (especially when wet), and on curves (braking and skidding) (Goeft and Alder 2001; White et al. 2006; Chiu and Kriwoken 2003). Such damage may increase trail incision, soil erosion, water runoff, and widening. However, limited research has 
been undertaken on how such impacts may differ with use intensity (e.g., under racing conditions) or duration. In some locations, recent growth in mountain biking has meant that sites with previously only seasonal recreation are now exposed to year-round impacts. For example, in alpine ski resorts such as Canada's Whistler Blackcomb, summer revenue from mountain biking now represents approximately $75 \%$ of winter snow recreation revenue (TRC 2005, Whistler Blackcomb undated) eliminating the period for environmental recovery between ski seasons. Chiu and Kriwoken (2003) have shown that such impacts on erosion are cumulative, although curvilinear. After rapid initial erosion, the rate of change declines. The longitudinal studies needed to determine the long term chronic impacts of mountain biking are lacking, yet Buckley et al. (1999) noted, that even passive tourism causes impacts for the lifetime that the recreation activity is practised.

Although there is a paucity of comparative studies, the impacts on the flora and fauna of competitive mountain biking are likely to be greater than recreational biking and/or bush walking. This is because the essential thrill element of racing demands technically challenging courses involving steeper up/downhill slopes, faster, harder braking, more intense use, cutting corners, wet sections and jumps/ drop offs, together with substantial vegetation trampling from riders and spectators off-track. A German study of a competitive mountain bike racing event showed soil compaction resulting from bikes occurred to a shallower depth compared to the impact of spectators. Compaction from the wheels of the bikes was less, but deeper and recovered within 19 months whereas the impacts of spectators persisted for longer (Wöhrstein 1998). Australian studies of such racing events have found that soil loss at sharp corners was greater than on straight sections (Hawes 1997). Under wetter conditions there were increased offtrail vegetation impacts and trail widening, especially on steep slopes and on corners. Racing under such conditions has also been shown to increase off-trail vegetation impacts and trail widening (Goeft and Alder 2001), although in another Australian study the damage reported was less severe (Chui and Kriwoken 2003).

Owing to the lack of comprehensive assessment of its impacts, especially over long term use (White et al. 2006), mountain biking remains restricted and/or banned in some ecologically fragile areas, such as parts of the Cairngorm Mountains in Scotland (Hanley et al. 2002) and wilderness zones of the Greater Blue Mountains World Heritage Area, Australia (NPWS 2001).

The impacts emanating from mountain biking are not necessarily unique; effectively all outdoor recreational pursuits in natural areas can have adverse effects on the local environment (Lynn and Brown 2003). However, it is the markedly different motivation driving participation, especially in the more extreme versions (e.g., excitement, risk, speed, competition - Tiedeman 2002; Leberman and Mason 2000; Chiu and Kriwoken 2003; Cessford 1995) and the construction of trails and/or infrastructure to gain such outcomes (Cessford 1995; TRC 2005), together with their extent (e.g., MATC 2010) and the very large number of participants involved that potentially sets this sport apart. Unlike other forms of adventure recreation, which are typically niche activities, mountain biking, especially in its cross-country/recreational form, is today a true 'mass market' form of adventure recreation for all the family (TRC 2005; TRC/EKOS 2007).

\section{Potential impacts on native fauna}

Impacts of recreation, including mountain biking, on the physical environment (Priskin 2003; Chiu and Kriwoken 2003; Ewert et al. 2006; Hawes 1997) and associated flora (Whinam and Chilcott 1999; Groom et al. 2007; Pickering and Hill 2007) are typically the most obvious impacts in natural areas and the most commented upon (e.g., Symmonds et al. 2000; Leung and Marion 1996; Thurston and Reader 2001; Martin et al. 1989). In contrast, knowledge of recreational impacts on fauna is relatively limited (Taylor and Knight 2003; Knight and Cole 1995), especially regarding adventure recreation (Hardiman and Burgin, 2010a, 2011b, c), except where the species is the target of the recreational activity (e.g., bottlenose dolphin Tursiops. sp., Shark Bay - Bejder et al. 2006; Mann et al. 2000; yellow eyed penguin Megadyptes antipodes - McClung et al. 2004; harp seals Phoca groenlandica Kovacs and Innes 1990).

The immediate response of individual animals to recreational disturbance is usually either death or behavioural change (e.g., physiological, food habitats, nest abandonment; Knight and Cole 1995; Lathrop 2003). Many of these behavioural responses are short term (Cassirer et al. 1992). For example, in a study that compared the effect (alert distance, flight distance, distance moved) of mountain bikers and hikers on bison Bison bison, mule deer Odocoileus hemionus, and pronghorn antelope Antilocapra americana, Taylor and Knight (2003) found no difference among species in response to the two types of recreationists. There was a $70 \%$ or greater chance (mule deer 96\%) of recreationists flushing all three species from within $100 \mathrm{~m}$ from the trail. Birds have also been found to be sensitive to pedestrian traffic. For example, the blackcrowned night heron Nycticorax nycticorax was observed to change behaviour in the presence of pedestrians (and canoeists), at least in the breeding season. In the presence of humans, birds spent more time scanning (increased vigilance), freezing (anti-predator behaviour) and less time grooming and sleeping (Esteban et al. 2007). Most such studies of disturbance of birds by pedestrian recreationists have found that there was a reduction in the size of the breeding population, presumably due to abandonment of the site, although the success of the remaining birds was typically not affected (Knight and Cole 1995). However, responses may vary. For example, Miller et al. (1998) studied the influence of recreational trails on bird breeding and found that composition of bird species was lower near trails than away from them and generalist species were more abundant near trails than specialists. Nest predation, however, was greater near trails than away from them. In contrast, Stake (2000) found no difference in density, return rates or age structure for the endangered golden-cheeked warbler Dendroica chrysoparia due to the introduction of mountain biking. 
While limited data are available on the impacts of birds and larger vertebrates, publications were found that directly addressed the impact of mountain biking on small animals. However, such species (e.g., small mammals, reptiles, invertebrates) would be less able to avoid the approach of mountain bikers, who travel more quickly and quietly than walkers. Lathrop (2003) reported that the effects of direct mortality due to mountain biking were 'virtually' unstudied although he suggested that anecdotal evidence indicated that small mammals are vulnerable and are killed. In a study of 1976 members of Bicycle Queensland, Heesch et al. (2010) examined the correlates of cycling injury (demographic characteristics, reasons for cycling, years of cycling as an adult, cycling frequency) for the previous year. Approximately 10\% were caused by a 'crash with an object on the road or path'. Since this included 'pothole, kerb, animal', and 'wet or gravel surface', we assumed that few accidents are reported to be caused by animals (including domestic animals). Despite these few recordings, moribund lizards and associated bicycle skid marks have been observed on an urban Brisbane bicycle track. It is likely that the most dangerous time for the local blue tongue lizard Tiliqua scincoides is soon after sunrise when local biking traffic is substantial and lizards take their first bask for the day. Snakes are also vulnerable: Australian red-bellied black snakes Pseudechis porphyriacus often lying across a track in the Blue Mountains National Park and are prone to being accidentally ridden over and killed. We predict that the risk of injury to animals is positively correlated with increasing numbers of bike riders in the same way that animal road kill is associated with high vehicle traffic levels.

Apart from direct injury by bikers, mountain biking trails (or any other pathway through natural areas) may indirectly impact on native species. Many small species are influenced by changes in the vegetation structure that occurs with disturbance at the edge of bushland. For example, the abundance of brown antechinus Antechinus stuartii, a small carnivorous marsupial, was found to respond to structural components of its habitat including understorey height and complexity, litter depth and the absence of logs (Knight and Fox 2000) all of which may be modified in the presence of a mountain biking track or built infrastructure (e.g. jumps, boardways, teeter-totters) in a national park.

Predation may also be greater at the interface of the tracks and natural areas. For example, Anderson and Burgin (2002) found that abundance of the small common Lampropholis skinks (L. delicata, L. guichenoti) at the edge of remnant bushland plots, separated only by the width of power line corridors, was only half that of sites located at the core of such small remnants of natural bushland, showing the detrimental 'edge effect' of the dividing corridors. In a later study, Anderson and Burgin (2008) provided evidence that these differences were sustained, and that bird predation was the major factor for the differences in abundance between the edge and core. Mountain biking trails through natural bushland offer an equivalent interface that has the potential to attract animals, particularly reptiles that thermoregulate and expose them to predation and collision with bikers' wheels. For example, over a seven year period, Wotherspoon and Burgin (2011) collected 19 reptile species (33\% of the local recorded reptile fauna) as road kill on early morning excursions in Faulconbridge on a suburban road in a 50 $\mathrm{km}$ zone that abutted national park. These species are also likely to access trails within the local national park and therefore expose themselves to possible collision if it were a mountain biking trail. Use of the trail would also potentially expose native animals to predators, including feral species such as the red fox Vulpes vulpes that penetrate natural areas by moving along such paths (Catling and Burt 1995).

Apart from their potential to act as a conduit for species to penetrate into natural areas (e.g., foxes - Catling and Burt 1995; toads Rhinella marina [Bufo marinus] - Seabrook and Dettman 1996; Brown et al. 2006), there is substantial evidence that roads or trails may act as barriers to the movement of animals due to behavioural avoidance, the presence of a physical barrier or development of a home range along the physical barrier (Donaldson and Bennett 2004). The extent to which roads act as barriers to dispersal depends on the physical characteristics of the road (e.g., clearing width, road surface, traffic density) and the characteristics of the species (e.g., species, size, mobility, habitat requirements). Small species for example beetles, spiders and snails with relatively limited mobility will be more affected than larger, more mobile species. The barriers may be physical, behavioural or sociological (Mader 1984; Baur and Baur 1990). Development of a home range along physical barriers has the potential to interfere with social interactions (Barnett et al. 1978; Burnett 1992). For example, after initial research into areas near roads, the eastern chipmunk Tamias striatus, was found to avoid roads and their verges. This avoidance was independent of traffic volume (Ford and Fahrig 2008). In contrast, a study of road kill in peri-urban Sydney and regional New South Wales, Burgin and Brainwood (2008) found that there were higher numbers of animals killed on medium volume traffic roads compared to lower volume, local traffic ones or major highways. They also observed that compared to where there were either barriers on both sides of the road or none present there were fewer road kills than when a barrier was present along one verge.

In the terrestrial environment, movement of smaller animals such as beetles and snails are presumably more greatly affected by such barriers (Baur and Baur 1990; Mader 1984) although they may increase their longitudinal movement parallel with the road. However, while roads inhibit movement of small mammals they rarely prevent movement across them (e.g., Oxley et al. 1974; Barnett et al. 1978). Since mountain bike trails tend to be narrow they would be less of a challenge than roads for most vertebrates. Reptiles may be the exception since they seek open areas and/or warm substrates as basking sites. For example, Wotherspoon and Burgin (2011) found that species considered locally rare were found in disproportionately higher numbers as road kills. Individuals of two species, eastern small-eyed Cryptophis 
nigrescens and blind snake Ramphotyphlops nigrescens that had been seldom observed locally, were among the most common encountered road kills. While the low speed, suburban street that Wotherspoon and Burgin (2011) reported on has remained effectively unchanged for more than 20 years, species may become locally extinct as a result of new road development (Lunney et al. 2002) while the long-term viability of some vertebrate populations may be compromised (e.g., Jones 2000; Ramp and Ben-Ami 2006).

In addition to the age of the road, soils and/or habitat may also influence the impact on local species. For example, although mountain biking was not specifically mentioned, Ross et al. (2009) reported that bicycles contributed to the degradation of saltmash communities, habitats often present in coastal national parks. The impact of human trampling of benthic invertebrate habitat (pneumatophores and associated algae) and associated changes in gastropod communities at the landward - midregion of a temperate mangrove forest (the area of highest gastropod diversity) were observed to be substantial, even at the equivalent of 25 people walking through a $30 \mathrm{~cm}$ wide undisturbed area (Ross, 2006). Hardiman and Burgin (2011b) undertook a similar study to Ross (2006) in a very different environment. In a pristine canyon environment of the Greater Blue Mountains World Heritage Area with very sandy substrate and low nutrient waters, they found that even at much higher levels of trampling than Ross (2006) had used, abundance and diversity of aquatic invertebrates returned to pre-trampling levels within one week. The impact of mountain biking may therefore differ greatly, even between aquatic ecosystems.

\section{Appropriateness of national parks for mountain biking}

While there is a dearth of information on the impact of mountain biking trails on the movement of fauna, Donaldson and Bennett (2004) reviewed the implications for internal fragmentation of parks and reserves due to roads and associated traffic. They concluded that the major ecological impacts were habitat alteration; constriction of the paths of animal movement; barriers to the movement of fauna; potentially isolating populations and communities; collision; and a source of biotic and abiotic effects. It was their view that, 'often to a lesser degree' these impacts were equivalent for recreational tracks used by bushwalkers. Based on the findings of a number of abovementioned studies (see Wilson and Seney 1994; Thurston and Reader 2001; Chiu and Kriwoken 2003) mountain biking would appear to have less impact than motorised vehicles. However, in contrast to most other forms of recreation that use access roads and paths in national parks, mountain biking trails are likely to be much more extensive and, at least over steeper sections, situated in much more vulnerable areas for the integrity of the local soils (i.e., steep, downhill slopes). With its demonstrated increasing popularity, the volume of bikers will exacerbate such issues and undoubtedly place more pressure on local fauna and their habitats.
Impacts associated with new forms of recreation have traditionally been handled by land managers by establishing normative standards for the activity and then developing rules and regulations to manage it (Ewert et al. 2006). Models such as 'Limits of Acceptable Change' have been developed to support such legislative decisions (Stankey et al. 1985), but may be difficult to apply to mountain biking if there are fundamentally differing perceptions of what constitutes acceptable use of public areas among stakeholders with strongly-differing views. In matters of such conflict it is often difficult for land managers to maintain their position. As a consequence, a typical process associated with the introduction of new recreational activities into a (protected) natural area is (1) resistance, (2) conflict, (3) compromise, and finally (4) accommodation (Ewert et al. 2006). This has apparently been the experience with mountain biking in UK national parks. The issues tend also to be exacerbated because visitors and managers perceive impacts differently (e.g. Martin et al. 1989; Hardiman and Burgin 2010b).

The power of advocacy through formal groups (e.g., sport specific associations) and informal (e.g., weblogs, online fora, social networking media) are becoming more influential and sophisticated in determining the appropriateness of national parks for mountain biking. The reach of the internet among members of increasingly technologically-knowledgeable user groups further enhances their lobbying power. Such networking has resulted in changes in decisions. For example, in the 1990s, in three UK national parks such campaigns resulted in changes in the decisions of land managers. Mountain biking in Dartmoor was initially made a criminal offence, while Exmoor considered it an 'unsuitable activity' and Snowdonia attempted to ban mountain bikers from its bridleways. Public opinion campaigns have since forced mountain biking to become an accepted activity in these parks, despite continued opposition (Palmer 2006).

Natural area managers are increasingly confronted with threats of appeals and litigation against their efforts to restrict what they perceive to be inappropriate recreational activities within protected areas. Such conflict with recreationists can be supported by the associated tourism and retailing industries who have commercial interests in the use of areas for their sport (Sarre 1989). The trail ahead therefore requires serious consideration of how best to deal with mountain biking and the associated degradation of natural areas, and potential loss of plant and animal species.

Lessons for balancing the rising demand for mountain biking in national parks against nature conservation, could be gleaned from the long-term conflict over horse riding. In 1996, a national park's survey in New South Wales revealed that $60 \%$ of park visitors objected to recreational horse riding in parks (Ramsay 1996) despite it being viewed as an integral part of the Australian image (Beeton 1999). The conflict continues (Newsome et al. 2002). We suggest that this may well be the outcome for mountain biking if the issues are not addressed adequately. To minimise the potential for such protracted conflict over mountain biking (or indeed any other emerging sport), decisions must be based on: 
1. Sound ecological and social research;

2. Park management should genuinely engage with stakeholders (e.g., mountain bikers, other recreation users, relevant commercial interests, local residents, researchers) to develop options (these may include alternative venues to national parks);

3. Decisions, and clearly enunciated reasons that underpin these decisions should be widely disseminated; and

4. Monitoring activities, including studies to determine long term chronic impacts and on-going community attitudes on an on-going basis to ensure that changes in management decisions are underpinned by defensible research.

Without a strong strategic approach to mountain biking that includes community engagement, underpinned by quality ecological and social science, the outcome will be further degradation of natural areas and, at the least, loss of many animals if not major threats to populations. We also predict that there will be on-going conflict between mountain bikers and other recreationists and residents.

\section{References}

Anderson, L. and Burgin, S. 2002. The influence of woodland remnant edges on small skinks (Richmond, New South Wales) Austral Ecology 27: 630-637.

Anderson, L. and Burgin, S. 2008. Patterns of bird predation on reptiles in small woodland remnant edges in peri-urban north-western Sydney, Australia. Landscape Ecology 23: 1039-1047.

Baker, T. and Simon, J. 2002. Embracing risk. Pp. 1-25 in Embracing Risk: The Changing Culture of Insurance and Responsibility edited by T. Baker and J. Simon. University of Chicago Press, Chicago.

Barnett J.L., How R.A. and Humphreys W.F. 1978. The use of habitat components by small mammals in eastern Australia. Australian Journal of Ecology 3: 277-285.

Baur A. and Baur B. 1990. Are roads barriers to dispersal in the land snail Arianta arbustorum? Canadian Journal of Zoology 68: 613-617.

Beeton, S. 1999. Hoofing it - on four or two feet? Managing multi-trails and sites. Current Issues in Tourism 2: 211-225.

Bejder, L., Samuels, A., Whitehead, H., Gales, N., Manns, J., Conner, R., Heithaus, M., Watson-Capps, J., Flaherty, C. and Krützen, M. 2006. Decline in Relative Abundance of Bottlenose Dolphins Exposed to Long-Term Disturbance. Conservation Biology 20: 1791-1798.

Bradshaw, G. 2006. The Australian Bicycle Industry Report 2006. Bicycle Industries Australia. Graphyte Media Pty Ltd, Melbourne.

Brown, I. D. 1989. Managing for adventure recreation. Australian Parks and Recreation 25: 37-40.

Brown, G.P., Phillips, B.L. Webb, J.K. and Shine, R. 2006. Toad on the road: use of roads as dispersal corridors by cane toads (Bufo marinus) at an invasion front in tropical Australia. Biological Conservation 133: 88-94.

Buckley, R.C., Pickering, C.M. and Warnken, J. 1999. Environmental management for alpine tourism and resorts in Australia. Pp. 27-46 in Tourism and Development in Mountain Regions edited by P.M. Godde, M.F. Price and F.M. Zimmermann, CABI Publishing, New York.

Burgin, S. and Brainwood, M. 2008. Comparison of road kills in peri-urban and regional areas of New South Wales (Australia) and factors influencing deaths. Too close for comfort: Contentious issues in human-wildlife encounters edited by D. Lunney, A. Munn and W. Meikle. Royal Zoological Society of New South Wales, Mosman, Pp 137-144.

Burnett S.E. 1992. Effects of a rainforest road on movements of small mammals: mechanisms and implications. Wildlife Research 19: 95-104.
Carnicelli-Filho, S., Schwartz, G. M. and Tahara, A.K. 2010. Fear and adventure tourism in Brazil. Tourism Management 31: 953-956.

Cassirer, E.F., Freddy, D.J. and Ables, E.D. 1992. Elk responses to disturbance by cross-country skiers in Yellowstone National Park. Wildlife Society Bulletin 20: 375-381.

Catling P.C. and Burt R.J. 1995. Why are red foxes absent from some Eucalypt Forests in eastern New South Wales? Wildlife Research 22: 535-546.

Cessford, G. 1995. Off-Road Mountain Biking: A Profile of Participants and their Recreation Setting and Experience Preferences. Department of Conservation, Auckland.

Chiu, L. and Kriwoken, L. 2003. Managing recreational mountain biking in Wellington Park, Tasmania, Australia. Annals of Leisure Research 6: 339-361.

Davies, C. and Newsome, D. 2009. Mountain Bike Activity in Natural Areas: Impacts, Assessment and Implications for Management. A Case Study from John Forrest National Park, Western Australia. Technical Report Series, CRC for Sustainable Tourism, Queensland, Australia. http://www.crctourism.com.au/bookshop/ SearchResult.aspx?c=8. [Accessed 23 October 2012].

Donaldson A. and Bennett, A. 2004. Implications for the Internal Fragmentation of Australian Parks and Reserves. Technical Paper Series No 12, Parks Victoria, Melbourne.

Esteban, F.-J., Zollner, P.A., LeBlanc, C., Westphal, L.M. 2007. Responses of nestling black-crowned night herons (Nycticorax nycticorax) to aquatic and terrestrial recreational activities: a manipulative study. Waterbirds 30: 554-565.

Ewert, A., Attarian, A., Hollenhorst, S., Russell, K. and Voight, A. 2006. Evolving adventure pursuits on public lands: emerging challenges for management and public policy. Journal of Park and Recreation Administration 24: 125-140.

Ewert A. and Hollenhorst, S. 1994. Individual and setting attributes of the adventure recreation experience. Leisure Sciences 16: 177-191.

Faulks, P., Ritchie, B., Brown, G. and Beeton, S. 2008. Cycle Tourism and South Australia Destination Marketing. [online] CRC for Sustainable Tourism, Queensland, Australia. ISBN 9781920965495. http://www.crctourism.com.au/bookshop/ SearchResult.aspx. [Accessed 23 October 2012].

Ford, A.T. and Fahrig, L. 2008. Movement patterns of eastern chipmunks (Tamias striatus) near roads. Journal of Mammalogy 89: 895-903.

Gajda, M.S. 2008. U.K. mountain biking tourism - an analysis of participant characteristics, travel patterns and motivations in the context of activity and adventure tourism. M.Sc thesis, Edinburgh Napier University, Edinburgh, Scotland. 
Goeft, U. and Alder, J. 2001. Sustainable mountain biking: a case study from the southwest of Western Australia. Journal of Sustainable Tourism 9: 193-211.

Green, D.M. 1998. Recreational impacts on erosion and runoff in a central Arizona riparian area. Journal of Soil and Water Conservation 53: 38-42.

Green, D. 2003. Travel Patterns of Destination Mountain Bikers. [Online]. Available from: http://www.imba.com/resources/ science/travel_patterns.html. [Accessed 23rd October 2012].

Groom, J.D., McKinney, L.B., Ball, L.C. and Winchell, C.S. 2007. Quantifying off-highway vehicle impacts on density and survival of a threatened dune-endemic plant. Biological Conservation 135: 119-134.

Hall, T.E., Seekamp, E. and Cole, D.N. 2010. Do recreation motivations and wilderness involvement relate to support for wilderness management? A segmentation analysis. Leisure Sciences 32: 109-124.

Hanley, N., Alvarez-Farizo, B. and Shaw, W.D. 2002. Rationing an open-access resource: mountaineering in Scotland. Land Use Policy 19: 167-176.

Hardiman, N. and Burgin, S. 2010a. The efficacy of the freshwater crayfish Euasiacus spinifer as an environmental indicator of the impacts of canyoners in the Greater Blue Mountains World Heritage Area, Australia. Journal of Crustacean Biology 30: 771-778.

Hardiman, N. and Burgin, S. 2010b. Visitor impacts and canyon management in the Blue Mountains, Australia: canyoners' perspectives and wilderness management. Managing Leisure 15: 264-278.

Hardiman, N., and Burgin, S. 2011a. Canyoning adventure recreation in the Blue Mountains World Heritage Area (Australia): The canyoners and canyoning trends over the last decade, Tourism Management 32: 1324-1331.

Hardiman, N. and Burgin, S. 2011b. Effects of trampling on in-stream macroinvertebrate communities from canyoning activity in the Greater Blue Mountains World Heritage Area. Wetlands Ecology and Management 19: 61-71.

Hardiman, N. and Burgin. S. 2011c. Comparison of stream macroinvertebrate assemblages in canyon ecosystems of the Blue Mountains (Australia) with and without recreational traffic. Australian Zoologist 35: 757-769.

Hawes, M. 1997. Environmental Impacts and Management Implications of the 1997 National Mountain Bike Championships. Department of Conservation and Land Management, Canberra.

Heesch, K., Garard, J. and Sahlqvist, S. 2010. What factors are associated with cyclists getting injured? Correlates of cyclist injuries in Queensland. In 2010 Australasian Road Safety Research, Policing and Education Conference, 31 August - 3 September, 2010, National Convention Centre, Canberra.

Hendricks, W.W., Ramthun, R., and Chavez, D.J. 2001. The effects of persuasive message source and content on mountain bicyclists' adherence to trail guidelines. Joumal of Park and Recreation Administration 19: 38-61.

HSMBA undated. Hornsby Shire Mountain Biking Alliance. http://hsmba.info/ [Accessed 23rd October 2012].

IFSC 2010. International Federation of Sport Climbing. http:// www.ifsc-climbing.org [Accessed 23rd October 2012].

IMBA 2010. International Mountain Bicycling Association. http:// www.imba.com [Accessed 23rd October 2012].

Jones, C.D. 2000. Road upgrade, road mortality and remedial measures: impacts on a population of eastern quolls and Tasmanian devils. Wildlife Research 27: 289-296.
Jones, C.D. 2004. Evaluating visual impacts of near-view rock climbing scenes. Journal of Park and Recreation Administration 22: 39-49.

Knight, E.H. and Fox, B.J. 2000. Does habitat structure mediate the effects of forest fragmentation and human-induced disturbance on the abundance of Antechinus stuartii? Australian Journal of Zoology 48: 577-595.

Knight, R.L. and Cole, D.N. 1995. Wildlife responses to recreationists. Pp. 51-70 in Wildlife and Recreationists: Coexistence through Management and Research edited by R.L. Knight and K.J. Gutzwiller, Island Press, Washington DC.

Koepke, J. 2005. Exploring the Market Potential for Yukon Mountain Bike Tourism. http://www.tc.gov.yk.ca/pdf/ PotentialforMtnBikeTourisminYT2004.pdf [Accessed 23rd October 2012].

Kovacs, K.M. and Innes, S. 1990. The impact of tourism on harp seals (Ploca groenlandica) in the Gulf of St. Lawrence, Canada. Applied Animal Behaviour Science 26: 15-26.

Lathrop, J. 2003. Ecological impacts of mountain biking: a critical literature review, June 2003, Wildlands CPC, Pp. 1-5 http://www.wildlandscpr.org/ecological-impactsmountain-biking-critical-literature-review [Accessed 23rd October 2012].

Leberman, S. and Mason, P. 2000. Mountain biking in the Manawatu Region: participants, perceptions, and management dimensions. New Zealand Geographer 56: 30-38.

Leung, Y., Marion, J.L. 1996. Trail degradation as influenced by environmental factors: a state-of-the-knowledge review. Journal of Soil and Water Conservation 51: 130-136.

Lunney, D., Matthews, A., Moon, C. and Turbill, J. 2002. Achieving fauna conservation on private land: reflections on a ten-year project. Ecological Management and Restoration 3: 90-96.

Lynn, N.A. and Brown, R.D. 2003. Effects of recreational use impacts on hiking experiences in natural areas. Landscape and Urban Planning 63: 77-87.

Mader H.J. 1984. Animal habitat isolation by roads and agricultural fields. Biological Conservation 29: 81-96.

Mader H.J., Schell C. and Kornacker P. 1990. Linear barriers to arthropod movements in the landscape. Biological Conservation 54: 209-222.

Mann, J., Connor, R.C., Barre, L.M. and Heithaus, M.R. 2000. Female reproductive success in bottlenose dolphins (Tursiops sp.): life history, habitat, provisioning, and group-size effects. Behavioural Ecology 11: 210-219.

Martin, S. R., McCool, S. F. and Lucas, R. C. 1989. Wilderness campsite impacts: do managers and visitors see them the same? Environmental Management 13: 623-629.

MATC 2010. Mountain Biking in Moab. Moab Area Travel Council. http://www.discovermoab.com/biking.htm. [Accessed 23rd October 2012].

McClung, M.R., Seddon, P.J., Massaro, M. and Setiawan, N. 2004. Nature-based tourism impacts on yellow-eyed penguins Megadyptes antipodes: does unregulated visitor access affect fledging weight and juvenile survival? Biological Conservation 119: 279-285.

Miller, S.G., Knight, R.L. and Miller, C.K. 1998. Influence of recreational trails on breeding bird communities Ecological Applications 8: 162-169.

NBDA 2010. Leading bicycle retain to excellence. National Bicycle Dealers Association. http://nbda.com [Accessed 23rd October 2012]. 
Newsome, D., Milewski, A., Phillips, N. and Annear, R. 2002. Effects of horse riding on national parks and other natural ecosystems in Australia: implications for management. Journal of Ecotourism 1: 52-74.

NPWS. 2001. Blue Mountains National Park: Plan of Management. Hurstville: National Parks and Wildlife Service.

OTES 2010. Home Page. Over the Edge Sports. http://www. fruitamountainbike.com/ [Accessed 23rd October 2012].

Oxley D.J., Fenton M.B. and Carmody G.R. 1974. The effects of roads on populations of small mammals. Journal of Applied Ecology 11: 51-59.

Palmer, C. 2006. Mountain biking: settling into middle age - or clicking up a gear? Byway and Bridleway 3: 33-34.

Pickering, C.M. and Hill, W. 2007. Impacts of recreation and tourism on plant diversity and vegetation in protected areas in Australia. Journal of Environmental Management 85: 791-800.

Priskin, J. 2003. Physical impacts of four-wheel drive related tourism and recreation in a semi-arid, natural coastal environment. Oceans and Coastal Management 46: 127-155.

Puchan, H. 2005. Living "extreme": adventure sports, media and commercialisation. Journal of Communication Management 9: 171-178.

Ramp, D. and Ben-Ami, D. 2006. The effect of roadbased fatalities on the viability of a peri-urban swamp wallaby population. Journal of Wildlife Management 70: 1615-1624.

Ramsay, A. 1996. Wilderness - what do the managers think? Australian Parks and Recreation 32: 19-20.

Ride Rotorua undated. Welcome to 100\% MTB heaven. http:// www.riderotorua.com/ [Accessed 23rd October 2012].

Ross, P.M. 2006. Macrofaunal loss and microhabitat destruction: the impact of trampling in a temperate mangrove forest, NSW Australia. Wetlands, Ecology and Management 14: 167-184.

Ross, P.M. Minchinton, T.E. and Ponder, W. 2009. The ecology of molluscs in Australian saltmarshes. Saltmarshes in Australia edited by N. Saintilan, in CSIRO Publishing, Melbourne, Pp. 67-107.

Sarre, R. 1989. Risk management in recreation: legal dilemmas and legal solutions. Australian Parks and Recreation 25: 7-14.

Seabrook W.A. and Dettman E.B. 1996. Roads as activity corridors for cane toads in Australia. Journal of Wildlife Management 60: 363-368.

Stake, M.M. 2000. Impacts of mountain biking activity on golden cheeked warblers at Fort Hood, Texas. In: Endangered Species Monitoring and Management at Fort Hood Texas: 2000 Annual Report, Fort Hood Project, The Nature Conservancy of Texas, Fort Hood.

Stankey, G.H., Cole, D.N., Lucas, R.C., Petersen, M.E. and Frissell, S.S. 1985. The Limits of Acceptable Change (LAC) system for wilderness planning. General Technical Report INT - 176. Intermountain Forest and Range Experiment Station, United States Department of Agriculture, Forest Service, Ogden.
Starr, M., Gordon, D. and Begun, B. 2006. Board crazy. Newsweek, 27th February, 147(9).

Sun, D. and Walsh, D. 1998. Review of studies on environmental impacts of recreation and tourism in Australia. Journal of Environmental Management 53: 323-38.

Symmonds, M.C., Hammitt, W.E., Quisenberry, V.L. 2000. Managing recreational trail environments for mountain bike user preference. Environmental Management 25: 549-564.

Taylor, A.R. and Knight, R.L. 2003. Wildlife responses to recreation and associated visitor perceptions. Ecological Applications 13: 951-963.

Thurston, E. and Reader, R.J. 2001. Impacts of experimentally applied mountain biking and hiking on vegetation and soil of a deciduous forest. Environmental Management 27: 397-409.

Tiedeman, B.G. 2002. Michigan Mountain Biking Association Marketing Research. Michigan Mountain Biking Association, Waterford.

TRC 2005. Forestry Commission Scotland: an Ambition for Forest Cycling and Mountain Biking - Towards a National Strategy. Final Report. Tourism Resources Company. http://www. forestry.gov.uk/pdf/forestcyclingandmountainbiking.pdf/\$FILE/ forestcyclingandmountainbiking.pdf. [Accessed 23rd October 2012].

TRC/EKOS. 2007. 7stanes Phase 2 evaluation: report for Forestry Commission Scotland, October 2007. Glasgow: Tourism Resources Company and EKOS Ltd.

Whinam, J. and Chilcott, N. 1999. Impacts of trampling on alpine environments in central Tasmania. Journal of Environmental Management 57: 205-220.

Whistler Blackcomb undated. Whistler Mountain Bike Park. http://www.whistlerbike.com/index.htm. [Accessed 23rd October 2012].

White, D.D., Waskey, M.T., Brodehl, G.P. and Foti, P.E. 2006. A comparative study of impacts to mountain bike trails in five common ecological regions of the Southwestern U.S. Journal of Park and Recreation Administration 24: 21-41.

Wotherspoon D. and Burgin S. 2011. The impact on native herpetofauna due to traffic collision at the interface between a suburban area and the Greater Blue Mountains World Heritage Area: an ecological disaster? Wildlife response to disasters edited by C. Dickman, D. Lunney and P. Banks, in Australian Zoologist 35: 1040-1046.

Wilson, J.P. and Seney, J.P. 1994. Erosional impact of hikers, horses, motorcycles, and off-road bicycles on mountain trails in Montana. Mountain Research and Development 14: 77-88.

Wöhrstein, T. 1998. Mountainbike und Umwelt: Ökologische Auswirkungen und Nutzungskonflikte. Pirrot Verlag and Druck, Saarbrücken-Dudweiler. 